\title{
Measuring Islamic Banking Performance Using Islamic Ethics Perspective
}

\author{
Satia Nur Maharani ${ }^{1, *}$ Setya Ayu Rahmawati ${ }^{2}$ \\ 1,2 Universitas Negeri Malang Malang \\ "Corresponding author. Email: satia.nur.fe@um.ac.id
}

\begin{abstract}
This article seeks to present a new framework in the performance measurement model of Islamic banks based on the Maqasid Syariah concept. Considering that until now the Islamic Bank performance measurement model still uses conventional measurements such as Camels, Value Added, BSC which are substantially unable to touch and measure Islamic values. While the practice of Islamic banks is to unite the moral and ideological values of Islam in business, social and propaganda. So that the financial aspect is not a top priority and the only one in measuring the success and achievements of Islamic Banks. The performance measurement model based on Maqasid Sharia, brings together financial attributes and sustainable development in individual, economic, ecological and social aspects. It is hoped that the model will be able to provide a new khanasah in translating the "ranking" of successful performance in the halal financial industry, especially Islamic banks.
\end{abstract}

Keywords: Maqashid Al-Shari'ah, Islamic Bank, Performance Measurement

\section{INTRODUCTION}

The development of industries that are built based on Islamic values is growing. Starting from the financial industry, interest in implementing Islamic economics has transformed in various business and trade industries such as food, pharmaceuticals, tourism and so on. This gave birth to the term "halal industry" to provide a symbol for industries that seek to comply with Islamic law. Halal is not only related to products, but also includes many aspects including the process, results and distribution.

As a business that has a foundation of religious values, Islamic banking as part of the halal financial industry must practice in accordance with what has been determined in Islamic law. "Halal" banking refers to the financial industry which produces halal products, provides halal services, and they do not violate Islamic law in all aspects, especially financial aspects. One important perspective in the practice is the important implementation of maslahah (welfare). Halal financial industry players play a role as an agent that brings together social justice and economic growth. Then the standard maslahah can be an ethical measurement tool related to Islamic bank products and their implementation. Besides that, maslahah can also be used as a parameter to measure customer satisfaction performance. It is true that
Islamic banks must be able to adapt to changes that encourage creativity, dynamics, and flexibility [1]. However, adaptation must be directed to achieve higher life goals in Islam called maslahah in the frame of Maqashid Al-Shari'ah [2]. Therefore to measure the success of performance in Islamic banks is how capable the bank is to reach every element of Maqashid Al-Shari'ah.

In general, financial indicators are parameters used in measuring the performance of Islamic banks. CAMELS (Capital, Asset, Management, Earning, Liquidity, Sensitivity of Market Risk) and EVA (Economic Value Added, Balance Score Card (BSC) are some financial ratios that are applied to measure the performance of Islamic banks. However, there are differences in perspectives in principles and objectives between Islamic banks and conventional banks Using the Umer Chapra paradigm, Al-Amine [3] states that Islamic banks as part of Islamic economics have four objectives, namely realizing economic prosperity within the framework of Islamic norms, maintaining unity (ukhuwah) in the frame of justice, achieving justice in income distribution and realizing individual freedom in the context of Islamic economics, so CAMELS, EVA and BSC are considered unable to measure the objectives of Islamic banks, Sirajudin, Sulayman, Triyuwono $[4,5,6]$ explain several aspects of why CAMELS, EVA and the BSC is 
considered unsuitable as a concept of measuring the performance of Islamic financial institutions, they explained that basic ethical values that underlie the three measuring tools is a modern economic system where the ethical value of utilitarianism which assesses good and bad, right and wrong, is just based on the consequences of an action, on hedonic utility and material happiness. Consequently the financial aspect is placed as the most important indicator in representing the success of performance.

Therefore the concept of measurement in Islamic banks must be different from conventional banks. These differences are from philosophical concepts and theories to measurable performance elements. The concept of performance measurement in Islamic banks must stand on a foundation and be based on the vision of Sharia in this case Maqashid Al-Shari'ah.

\section{ISLAMIC ETHICS PRESPECTIVE}

\subsection{Maqashid Al-Shari'ah}

Terma maqashid comes from Arabic, which means principle, purpose, target or purpose. When synergized with the term al-shari'ah are the objectives of Islamic law contained in every Islamic rule [7]. Imam Al-Ghazali a prominent Islamic scholar and scientist in the 11th century divided Maqashid al-shari'ah into five important elements, namely guarding the faith (dien), self-preservation (nafs), preserving intelligence (Aql), protecting descendants (Nasl) and keep wealth (Mal). Flexibility, dynamics, and creativity in social policy are carried out by safeguarding these elements. Therefore, Maqasid Sharia is often translated as the goals and objectives of Islamic law designed to protect all elements to help the development and improvement of the conditions of human life on earth [8]. Two centuries later, Imam Shatibi supported Imam Ghazali's thoughts regarding Maqasid Shari'a (the aim of Islamic law) was to spread ethical values of compassion and guidance, establish justice, dispel prejudice and reduce difficulties in cooperation and mutual processes in the family, community and life [9].

In line with the thoughts of Imam Ghazali, Laldin and Furqani [10] stated that there are five things that become the aim of Maqashid al-shari'ah, namely first, to protect life as a fundamental right for all humanity. Second protect the mind as a gift from God and protect the difference between humans and other God's creations. Third, protect offspring so that the lives of all humans will continue. Fourth, protect and guarantee religious freedom and practice of worship not only for Muslims but all followers of religion. Fifth, protect the wealth and life of every human being so that there is no oppression and tyranny in terms of obtaining wealth. The ultimate goal of maqashid al-shari'ah is Allah through the unification of the implementation of religion which is related to the afterlife and worldly life which is related to world affairs.

The maqashid al-shari'ah articulation offered by Bedoui [11] provides an outlet for normative values on an empirical level for concrete implementation in various aspects, one of which is the measurement of the performance of Islamic banks.

\subsubsection{Business and Social Characteristics of Islamic Banks}

Islamic banks are a part of Islamic economics that have a normative objective characterized by Islamic Sharia. The goals are economic prosperity, universal brotherhood and justice, fair distribution of income and the right of individuals to obtain social welfare within the Islamic Shari'ah frame [12]. The rules provide absolute conditions that all of these goals are for the service of God. Profits are not merely tangible material or money but rather how the process and results to achieve these benefits are true in accordance with the provisions. In addition, in achieving its objectives oriented not only to safety in the world but also afterward (afterlife). In the end, Islamic banks in practice carry the mission to achieve the above objectives as a step of devotion to God to get salvation in the world and beyond. It can be said directly that an Islamic bank to achieve the above objectives is by Maqashid al-Shari'ah [13].

To achieve the above objectives, some of the characteristics of Islamic banks that become the basic values in concrete implementation of Islamic banks can be explained as follows:

1. Islamic Ontology is the most substantial character in Islamic bank practices which prohibits the practice of riba (interest-based transactions), gharar (gambling), speculative transactions and products that violate Islamic norms [12].

2. The Islamic bank contract system is Profit and loss sharing (PLS) which is derived in all their products. Islamic banks prioritize mudharabah and musharakah which best represent social, economic and propaganda goals as the core of the al-Shariah maqasid. This is an effort to realize "a society that contributes" in empowering individuals to turn society into a social capital characterized by "ihsan" [14].

Conventional banks in carrying out their intermediation function are farther away from the real sector so that it triggers excessive non-real loans and results in financial crises. This is different from Islamic banks that offer sharia rules in financing for the real sector so that the increase in income is in line with the increase in the real sector [15]. This has an impact on improving systemic social welfare and stability and productivity of financial turnover.

Social problems such as poverty and environmental issues, in sharia law are also an important part of attention so that being ethical is no longer an option for Islamic banks but has become part of the principle of how they are and exist in life [16].

The above character provides at least three dimensions of performance that are important characteristics in the operational practices of Islamic banks [17]. First, Islamic banking in carrying out its operations, as part of the facets of 
economic entities, makes profit an objective. However, this advantage is achieved through operations that adhere to Islamic norms. Second, Islamic banks in carrying out their duties and functions must uphold the principles of justice and brotherhood. Third, Islamic banks in distributing income and wealth must be equal. One of the values which is the basis of the vision and mission of Islamic banking is that all of its essential resources belong to God. So that Islamic reform must be committed to that perspective by distributing resources evenly to build productive societies. So, it can be said that Islamic banks have a role not only as a business entity, but also a social entity and propaganda through product development based on Islamic ethical and moral principles

Some previous studies such as Alam et al. [14] measured the performance of sharia microcredit using the maqashid alshari'ah perspective because it was felt that the conventional scoring system could not evaluate performance in terms of achieving sharia objectives for the sharia microcredit model. Rafikov and Saiti [18] use the maqashid al-shari'ah approach to analyze the practice of financial speculation in general and foreign exchange, especially in risk management. [19] conducted an analysis of the Corporate social responsibility (CSR) of Islamic financial institutions to find out to what extent the CSR program represented the maqashid al-shari'ah. [20] conducted an evaluation of social performance in Islamic banks using the maqasid al-Shari'ah perspective.

\subsubsection{Measuring Islamic Bank Performance in Da'wah Social Business Functions}

As explained above, social objectives play a very important role through internalizing Islamic values in the practice of Islamic banks. Therefore, failure and success of social performance is one important indicator that must be measured. Apart from that the basic value of Islam requires Islamic banks to transform missionary mission in terms of implementing Islamic economic principles. Then the mission mission is the consequence of the performance of Islamic banks. This has an impact on assessment indicators that must be able to effectively accommodate and measure business, social and propaganda performance.

While what has developed and existed so far is conventional measurement tools such as CAMELS, EVA, BSC which provide the greatest attention on the financial aspects. It can be said that all conventional performance measurement models do not have the tools to measure the performance of Islamic banks on social and propaganda aspects. [6] which states that the behavior of Islamic bank management that applies the conventional performance measurement model as a performance measurement tool, has an impact on the co-opting of values that focus on financial goals as a top priority. The orientation of Islamic banks in the aspects of business, social and proselytizing will be reduced to banks that are only material and individual oriented so as to cause dysfunctional behavior of Islamic bank management as the authority holder in carrying out bank operations.
The current practice of Islamic banks, in many cases, is not in accordance with the required sharia standards. When compiling financial products, commitments to adhere to sharia rules and fulfill greater social welfare responsibilities must be believed and implemented [21]. For this reason, it is necessary to have a measurement that is able to touch the aspects of business and social propaganda as a form of performance evaluation of Islamic banks in carrying out sharia rules. If not, Islamic banks are only limited to symbols, but their functions and operations are no different from conventional banks. Especially because the Islamic banking system is very different from conventional banking.

The most fundamental difference, especially in the Islamic worldview of Islamic banks. This fundamental difference will lead to differences in formulation or performance evaluation models. [8] concluded that the difference in the Islamic economic system and other economic systems rests on three main things: (1) Islam's view that the world is a medium to get God's pleasure (2) The purpose of life is worship (3) Strategies or Policies must be in accordance with sharia rules [8]. These different views have an impact on the practice of Islamic banks in the process, strategy and evaluation. These values are not only expressed in terms of the legality of certain product fiqh, but more than that they must have a broad impact on economic and social aspects as a consequence of efforts to achieve Maqashid sharia.

\subsubsection{Performance measurement for Halal Banks based on Maqashid Al-Shari'ah}

Performance can be interpreted as a consequence and result of predetermined goals, objectives and targets. For strategic planning and program implementation, objectives are important tools that serve as the basis for determining business strategies and evaluating performance. More than that, the relationship between goal achievement and performance evaluation is to validate the level of relevance between implementation and policy making [22]. Thus, without an evaluation of management performance will never know whether the strategy that has been run goes according to plan. Regarding Islamic banks that have broader, comprehensive and holistic objectives, performance evaluation is required to have indicators that are able to validate all holistic implementations and policies. The performance measurement model allows a benchmark for Islamic banks to assess the extent to which objectives have been achieved.

The performance measurement model for Islamic banks must measure the extent to which the Islamic vision is implemented where the work commitment is not only on financial aspects but also non-financial [23]. This can be approached using the maqashid al-shari'ah perspective. The concept of maqashid al-shari'ah is an interesting subject of discussion in scientific studies due to the rapid development of the sharia industries. The concept of halal is of concern due to the high value of the substance it carries, named to get God, it must be holy. Al-Ghazali identified five elements which are the basic needs in human life in the version of the Maqasid al- 
Shari'ah, namely (1) human self (human self); (2) faith (faith); (3) intelligence (intellect); (4) posterity and (5) wealth. Underestimating the importance of one element and the other it shows harm to people's lives (other views are given regarding the elements of the al-Shari'ah maqasid, tahdzib alfard (individual/self-education), iqamah al-adl (justice), and maslahah (benefits/welfare). [11] articulates the normative concept of maqashid al-shari'ah more concretely as follows:

Table 1. The Normative Concept of Maqashid Al-Shari'ah

\begin{tabular}{|l|l|}
\hline $\begin{array}{l}\text { Safeguarding the value of } \\
\text { human life }\end{array}$ & $\begin{array}{l}\text { Faith } \\
\text { Human rights }\end{array}$ \\
\hline $\begin{array}{l}\text { Safeguarding the human } \\
\text { self }\end{array}$ & $\begin{array}{l}\text { Self } \\
\text { Intellect }\end{array}$ \\
\hline Safeguarding the society & $\begin{array}{l}\text { Posterity } \\
\text { Social entity }\end{array}$ \\
\hline $\begin{array}{l}\text { Safeguarding the physical } \\
\text { environment }\end{array}$ & $\begin{array}{l}\text { Wealth } \\
\text { Environment (Ecology) }\end{array}$ \\
\hline
\end{tabular}

When examined, maqashid al-shari'ah protects all aspects of both finance represented by wealth and non-finance, namely faith, self-intelligence and descent. These elements were developed and derived in the form of performance measurement indicators for maqasid al-Shari'ah to evaluate the processes, work programs and products in Islamic banks.

\subsection{Maintaining Harmonization of Life Values: Protection Against Faith}

Faith is the most fundamental perspective in Islam, influencing personal, attitudes, lifestyles, preferences and ways of dealing with people and the environment. Satisfaction in meeting material and psychological needs in the context of faith is a union between the desire to obtain the world and the spiritual [24]. Muslims in maximizing the satisfaction of needs but remain within the scope of their faith by uniting the moral and ideological values of Islam in their intentions, ideas and behavior. If faith is brought in the context of an Islamic bank, the process, distribution and results of an Islamic bank are to unite the moral and ideological values of Islam. This means how Islamic banks still maintain and preserve faith in their concrete implementation [25].

If analogous in the aspect of consuming food, a Muslim is encouraged to consume nutritious and required halal both the process of getting and elements of food. Why is that because it refers to the Koran physical health is supported by spiritual health, so it is always connected between moral and Islamic ideology in consuming food. So an Islamic bank to be considered healthy both physically (financial) is not enough if it is not supported by a healthy non-physical (nonfinancial). Islamic banks refer to al-Quran Surat Al-Arafraf 32 must meet the elements of at-tayyibat and ar-rizq. [26] explains that at-tayyibat means good, pure, clean and beneficial things which come from the best fortune. Thus the
Islamic bank in its comprehensive implementation includes values in Islam, which show the values of goodness, purity, and virtue. Meanwhile ar-rizq means pious provision as a form of divine giving where this is the connotation that what the Islamic bank gets is from God. The idiological consequences of Islam are profits and assets both human resources and other resources as a whole are from and belong to God [7]. Islam provides a complete and comprehensive guide on how to manage Islamic banks as determined by God, so maintaining faith is one of the most important needs that will guide Islamic banks to worship and shape human morals

Moving on from the above review of the commitment to safeguard and preserve faith in the Islamic Bank is absolutely done as part of the "work" of management. Why is that because faith is the main force so that Islamic banks in carrying out their functions and responsibilities are consistent in uniting the morals and ideological values of Islam to remain at-tayyibat and ar-rizq. Maintaining and preserving faith can be done by protecting the fulfillment of the pillars of Islam in this case Sadaqah, prayer, alms, fasting, and pilgrimage. So maintaining and protecting faith can be derived in a number of performance indicators namely the first dimension, supervision of worship with several elements namely protecting prayer, protecting quran, protecting zakat. The second dimension, the right to obtain halal with several elements in the form of products and services that are easy and inexpensive, reduce elements of income that are not halal $\&$ unjust, the application of ethical values, products offered halal, and so on.

\subsection{Protecting Humanity: Dimensions of the Soul (Hifzu An-nafs) and Intellect (Hifžu 'alaql)}

Islam places life, physical and soul very important because all these elements will be held to account by God. World life and its aftermath are no longer seen as a balance but unite where the comfort of the afterlife is very dependent on what is lived physically and spiritually in the world [24]. Protecting the soul in the context of faith has been explained in the previous section, while in the context of humanity protecting the soul is done through the fulfillment of human rights to life, welfare, prosperity, safety and security physically and mentally [2]. The fulfillment of these human rights must again be consistent with the criteria revealed by Islamic rules as a consequence of the unification of moral and ideological values of Islam.

Ibn Ashur stated that the overall rule of Islam is to maintain the order of the lives of the people, welfare with integrity that starts from how the healthy mind of a Muslim interprets the meaning of well-being [27]. After being able to interpret the meaning of welfare according to Islamic ideology, the next effect on individual actions to achieve welfare. If transformed to an Islamic Bank, then safeguarding humanity is how the Islamic Bank seeks to achieve prosperity within the ideological frame of Islam. Islamic Bank seeks to achieve prosperity by refraining from activities that create social damage and disruption that threatens the economic life 
of the community. Freedom is not permitted if it disturbs peace and social harmony [8].

Thus, Islamic banks achieve prosperity in the perspective of Islam that is by looking at humans and the environment as a whole and the main concern is how to live according to Islam, get the pleasure of God. This puts Islamic banks beyond personal interests, namely achieving prosperity by making social life a part. Even in this case the Prophet Muhammad put people who work to get the family's livelihood is the same position with jihad, fasting during the day and praying on the third of the night. Islamic banks are driven by individuals who strive for prosperity that is not only self-serving but also social and environmental life to get the world and God.

Intelligence or intellectual is human potential to understand knowledge in the form of the signs of the universe (ayat kauniyah) and the teachings of Islam (ayat qauliyah). Through human intelligence understand Islam as a guide to life to live life, conversely without human intelligence to live life in a sad way [28]. For this reason, Islam firmly requires Muslims to seek and expand knowledge (thalabul ilmi) to improve the quality of intelligence.

Islamic banks are part of those who must carry out the order to protect and protect the intelligence of its resources. Islamic banks are responsible for maintaining and honing the intelligence of their resources through education, training, human resource research, and others. Islamic banks must also distance their resources from things that reduce intelligence such as alcoholic drinks and other goods that tend to reduce intellectual quality.

Moving on from the above explanation, the performance indicators of Islamic banks in maintaining humanity can be derived in several dimensions and elements, namely Care for employees through improving the quality of human resources and usury-free welfare, increasing knowledge, upgrading and developing expertise, creating awareness of Islamic banks. The higher the value obtained by Islamic banks in maintaining humanity, the higher the performance of Islamic banks in this aspect.

\subsection{Protect Social Life through Heredity}

Maintaining survival is by maintaining human bloodlines (nasl). The ideological principle of Islam that unites the comfort of the afterlife is very dependent on the attitude in the world to bring about the consequences of creating a clean and holy generation. Because life is inherently sustainable in the world and afterwards descent must be manifested in a sacred process through marriage and strict punishment for adultery [27].

Islamic banks in the maqasid shariah cannot be detached in protecting social life through heredity. The program and implementation plan is for the purpose of maintaining Islamic banks clean and holy. The next generation is inherited by clean and holy results and the generation is continuously ready to continue clean and holy programs and policies. Islamic banks maintain justice for current social life to protect the social justice of the next generation [29]. This performance can be derived in several dimensions and elements, namely first, the social dimension of justice with elements of policy objectives and environmental issues, equity in income, funding structure, measuring the minimum capital requirement (KPMM). Second, quantitative disclosure of cleanliness and division of assets with an element of justice in the distribution of welfare. Third, safeguarding the lives of employees and shareholders with the element of employee welfare shareholder welfare. Fourth, the distribution of income \& wealth with elements of liability from the personal and social income of the community. Fifth, community development with elements of zakat, shodaqoh and benevolent loans

\subsection{Protecting Material Life and Nature}

The basic principle of wealth in Islam is the belief that all belongs to God and humans are God's representatives on earth to manage wealth in rahmatan-lil-alamin (grace for the universe). Accountability to God for management and utilization is a consequence of God's representative. If this belief is transformed to an Islamic bank then in line with Islamic economics, the responsibility of an Islamic bank is no longer limited to shareholders, employees and customers but also the natural environment and the highest alms are to God [30]. The consequence for Islamic banks in obtaining profits, efforts and efforts must comply with the criteria set by Islamic law.

There is a limit for Islamic banks in the accumulation of material and natural wealth so as not to harm other parties, not allowed to waste and are prohibited from producing wealth from ways that neglect God. That does not mean that Islamic banks are not allowed to seek profits, because in principle, making profits is part of protecting material life. [31] emphasized that muslin preserves or preserves material wealth in at least five aspects, namely preserving wealth through protection of ownership, preserving wealth through acquisition and expansion, preserving wealth from the risk of damage, preserving wealth through the process of circulation and maintaining wealth through business to protect value. It's just that these five aspects are carried out within the framework of Islamic ideological rules,

Another important perspective is the belief that material wealth is essentially God's property so that it utilizes material and nature as a way of worshiping God. Maintaining material wealth not only seeks to obtain the material but also how the material is distributed fairly. That there are rights of others who need according to 8 asnaf in terms of zakat and other types of distribution, namely infaq and shodaqoh / alms. Therefore, one of the successful performances of an Islamic bank is the severity of zakat, infaq and shodaqoh that have been issued. This is very realistic, Islamic banks do not have any property because the property is inherently owned by God. Islamic banks are only tasked to regulate and utilize material wealth for physical and mental well-being in a lawful and sacred manner. How much prosperity is owned by Islamic banks depends on how much the benefits for others 
so that the emergence of wealth is mutualism with empathy and compassion [9].

Protection of the natural environment is part of the Muslim belief as God's representative. Muslims are encouraged to reflect the relationship between themselves and their environment in harmony to maintain ecological balance [15]. Islamic banks in their existence are required to respect nature and utilize it in the frame of godliness. Therefore the success of the performance of Islamic banks is also determined by the preservation of Islamic banks on the environment.
Moving on from this explanation, several dimensions and elements of Islamic bank performance in protecting material and natural life are earnings dimensions with elements of net income to liabilities, dimensions of shareholder interests with elements of the bank's ability to distribute dividends to shareholders, dimensions of asset quality and quality of management by element of bad credit ratio, quality of productive assets of Islamic banks, efficient operations. Other dimensions, elements and indicators can be seen in the table below.

Table 2. Performance Measurement Indicator Framework

\begin{tabular}{|c|c|c|c|c|}
\hline & OBJECTIVE & PERSPECTIVE & DIMENSION & ELEMEN \\
\hline \multirow{16}{*}{1} & \multirow{16}{*}{$\begin{array}{l}\text { Protecting Sharia } \\
\text { Consistency }\end{array}$} & \multirow{8}{*}{$\begin{array}{l}\text { Godliness } \\
\text { toward Allah }\end{array}$} & \multirow{3}{*}{ Worship Supervision } & Protecting Prayer \\
\hline & & & & Protecting Qur'an \\
\hline & & & & Protecting Zakat \\
\hline & & & $\begin{array}{l}\text { Easy and inexpensive } \\
\text { products and services }\end{array}$ & Distribution Function \\
\hline & & & $\begin{array}{l}\text { Reducing income elements } \\
\text { that are not hala/\& unfair }\end{array}$ & Interest Free Product \\
\hline & & & Application of ethical values & Derivatives of ethical values and norms \\
\hline & & & $\begin{array}{l}\text { The products offered are } \\
\text { halal }\end{array}$ & Product \\
\hline & & & & Ect. \\
\hline & & \multirow{4}{*}{$\begin{array}{l}\text { Maintaining } \\
\text { Internal Actors' } \\
\text { Intelligence }\end{array}$} & $\begin{array}{l}\text { Concern for employees } \\
\text { through improving the quality } \\
\text { of human resources and } \\
\text { welfare that are free of riba }\end{array}$ & Employees Aspect \\
\hline & & & $\begin{array}{l}\text { Justice and Transparency - } \\
\text { Board of Directors }\end{array}$ & $\begin{array}{l}\text { Composition, Appointment and } \\
\text { Reappointment, Board Meetings and } \\
\text { Salaries }\end{array}$ \\
\hline & & & $\begin{array}{l}\text { Justice and Transparency - } \\
\text { Committee Aspects }\end{array}$ & Appointment and Remuneration \\
\hline & & & $\begin{array}{l}\text { Justice and Transparency - } \\
\text { Sharia Supervisory Board }\end{array}$ & Sharia Supervisory Board \\
\hline & & Profit & $\begin{array}{l}\text { Investment in the Real } \\
\text { Sector }\end{array}$ & Investment Ratio in the Real Sector \\
\hline & & \multirow{3}{*}{$\begin{array}{l}\text { HR Quality } \\
\text { Improvement }\end{array}$} & Improvement of Knowledge & Scholarship \\
\hline & & & $\begin{array}{l}\text { Upgrade and Develop } \\
\text { Expertise }\end{array}$ & Training \\
\hline & & & $\begin{array}{l}\text { Creating Awareness of } \\
\text { Islamic Banks }\end{array}$ & Advertisement \\
\hline \multirow{8}{*}{ II } & \multirow{8}{*}{$\begin{array}{l}\text { Protecting Social } \\
\text { Life }\end{array}$} & \multirow{4}{*}{ Justice } & \multirow{4}{*}{$\begin{array}{l}\text { Justice in Welfare } \\
\text { Distribution }\end{array}$} & Qard Hasan dan Shodaqoh Fund \\
\hline & & & & Employee welfare \\
\hline & & & & Shareholders' Welfare \\
\hline & & & & Net Profit per Liability \\
\hline & & & Income\& Wealth Distribution & Liability from personal income \\
\hline & & Community & & Zakat, shodaqoh and benevolent loans \\
\hline & & Interest & Community development & Social Society \\
\hline & & & Social Indicator & $\begin{array}{l}\text { Environmental Objectives, Policy and } \\
\text { Issues }\end{array}$ \\
\hline & & & Justice & Justice in Revenue \\
\hline & & & Capital Adequacy & Funding Structure \\
\hline & & & Asset Quality & Bad Credit Ratio \\
\hline III & Protecting & Wealth & Management Quality & Efficient Operations \\
\hline & material life & vvealth & & $\mathrm{ROA}$ \\
\hline & & & Ability to generate protıts & ROE \\
\hline & & & & Loan to Asset Ratio \\
\hline & & & Liquidity & Deposit to Asset Ratio \\
\hline
\end{tabular}




\begin{tabular}{|l|l|l|l|l|}
\hline & OBJECTIVE & PERSPECTIVE & DIMENSION & ELEMEN \\
\hline & & another bank's health ratio & Ect. \\
\cline { 3 - 5 } & \multirow{2}{*}{ Nature } & Environmental Indicator & $\begin{array}{l}\text { Environmental Objectives, Policy and } \\
\text { Issues }\end{array}$ \\
\cline { 4 - 5 } & & & CSR for the environment \\
\hline
\end{tabular}

\section{CONCLUSION}

The practice of Islamic banks faces enormous challenges to maintain their existence in the arena of a capitalistic economic system that strongly supports the existence of conventional banks. To maintain consistency in competing services and products while adhering to sharia rules is a formidable challenge. This article is a conceptual work process through maqasid al-Shari'ah offering a new concept in measuring the performance of Islamic banks. Performance measurement is one of the bases for Islamic banks to achieve the best performance. For this reason, program planning and implementation of Islamic banks will focus on efforts to meet the success indicators of performance measurement tools. Maqasid al-shari'ah reflects the Islamic ethical value of justice, welfare and equality. According to this vision, performance is not limited to the financial dimension but also non-finance such as protecting social, propaganda and protecting nature. The dimensions derived from the Maqasid al-Shari'ah are to maintain the harmonization of the values of life: protection of faith, protect humanity: the dimensions of the soul (hifzu an-nafs) and intellect (hifżu 'alaql), protect social life through offspring and protect material life and nature. Each of these dimensions has elements that will be reduced back to measurement indicators in the next conceptual work.

\section{REFERENCES}

[1] T. Al-Mubarak, N. M. Osmani, Applications of Maqasid Al-Shariah and Maslahah in islamic banking practices an analysis, India, October 2010 [International Seminar on Islamic Finance].

[2] Ascarya, R. Sukmana, Modeling islamic financial institution performance measurement based on Maqashid Al-Shariah, Yogyakarta, June 2014 [Workshop on Maqasid Al-Shariah based on Index of Socio-Economic Development]

[3] M.A.B. Al-Amine, Product development and Maqasid in Islamic finance: towards a balanced methodology, Islamic Economic Studies, vol.23(1), 2015, pp.33-72.

[4] Sirajudin, Interpretasi Pancasila dan Islam untuk etika profesi akuntan Indonesia,. Jurnal Akuntansi Multiparadigma, vol. 4(3), pp. 456-466, 2013.

[5] H. I. Sulayman, Values-based curriculum model: A practical application of integrated 'Maqasid Al-Sharia' for wholeness development of mankind, Procedia Social and Behavioral Sciences, vol. 123, 2014, pp. 477-484.

[6] I. Triyuwono, Akuntansi Malangan: Salam satu jiwa dan konsep kinerja klub sepak bola, Jurnal Akuntansi Multiparadigma, vol. 6(2), 2015, pp. 290-303.
[7] J. Auda, Maqāṣid Al-Shari'ah: A Beginner's Guide, London: The International Institute of Islamic Thought, 2008a.

[8] M. U. Chapra, The Islamic Vision of Development in the Light of Maqasid al-Shariah, London: The International Institute of Islamic Thought, 2008.

[9] A. A. Lamido, Maqasid Al-Shari'ah as a framework for economic development theorization, International Journal of Islamic Economics and Finance Studies, vol. 2(1), 2016, pp. 27-49.

[10] M. A. Laldin, H. Furqani, Developing Islamic finance in the framework of Maqasid Al-Shari'ah, International Journal of Islamic and Middle Eastern Finance and Management, vol. 6(4), 2013, pp. 278-289.

[11] M. H. E. Bedoui, Shari'a-based ethical performance measurement framework, Chairs for Ethics and Financial Norms, Paris: Universite Paris, 2012.

[12] J. Auda, Maqasid Al-Shariah as Philosophy of Islamic Law, London: The International Institute of Islamic Thought, 2008b.

[13] B. K. Burton, G. G. Michael, The moral floor: A philosophical examination of the connection between ethics and business, Journal of Business Ethics, vol. 91(1), 2010, pp. 145-154.

[14] M.M. Alam, S. Hassan, J. Said, Performance of islamic microcredit in perspective of Maqasid Al-Shariah: A case study on Amanah Ikhtiar Malaysia, Humanomics, vol. 31(4), 2015, pp.374-384.

[15] M. A. Budiman, R. M. Amin, S. A. Yusoff, A. A. Adeyemi, Measuring Maqasid Al-Shari'ah at a micro level with special reference to the preservation of wealth, Aceh, March 2015 [The First International Conference on Shari'ah Oriented Public Policy in Islamic Economic System].

[16] W. Hamid, S. D. D. Ubud, S. Aisjah, Trade principles and sharia-adherence banking performance analysis by employing Maqasid Islamic sharia index approach: Study on Indonesian sharia bank, Russian Journal of Agricultural and Socio-Economic Sciences, vol. 11 (59), 2016, pp. 66-74.

[17] I. Alhuraish, C. Robledo, A. Kobi, A comparative exploration of lean manufacturing and six sigma in terms of their critical success factors, Journal of Cleaner Production, vol. 164, 2017, pp. 325-337.

[18] I. Rafikov, B. Saiti, An analysis of financial speculation: from the Maqasid Al-Shari'ah perspective, Humanomics, vol. 33(1), 2017, pp. 2-14.

[19] Y.S. Abubakar, Corporate social responsibility of Islamic financial institutions: a look from the Maqasid 
Al-Shariah (purpose of Shariah) approach, Business and Economics Journal, vol. 7(255), 2016, pp.1-4.

[20] M. Asutay, Harningtyas, Conceptualization of the second best solution in overcoming the social failure of Islamic banking and finance: Examining the overpowering of homoislamicus by homoeconomicus, Journal of Economics and Management, vol. 15(2), 2007, pp. 167-195.

[21] T. Saidi, Relationship between ethical and islamic banking systems and Its business management implications, South Africa Journal of Business Management, vol. 40(1), 2009, pp. 43-49.

[22] S. M. Dangulbi, A conceptual model of measuring performance efficiency of islamic banks: Objectives of islamic law (Maqasid Al-Shariah) approach, 2012 [Available at SSRN 2070397].

[23] M. A. Choudhury, Social heteronomy and contrasting economic epistemology a mathematical approach, Proceedia-Social and Behavioral Sciences, vol.140, 2014, pp. 27-36.

[24] A, N. Ahmad, A. A. Rahman, S. A. Rahman, Assessing knowledge and religiosity on consumer behavior towards halal food and cosmetic products, International Journal of Social Science and Humanity, vol. 5(1), 2016, pp.10-14.

[25] L. Ali, A. Ali, H. Khwaja, Comparison of islamic and conventional banking on the basis of riba and services: A case study of Peshawar region, International Review of Management and Business Research, vol. 2(3), 2013, pp. 837.

[26] M. Kahf, Ekonomi Islam: Telaah Analitik terhadap Fungsi Sistem Ekonomi Islam, diterjemahkan oleh Machnun Husein, dari judul asli The Islamic Economy: Analitical of the Fuctioning of the Islamic Economic System. Yogyakarta: Pustaka Pelajar, 2006.

[27] M. Dikko, A. Ghani, Maqasid Al-Sharia and Takaful operations: Issues and challenges in an emerging industry, Journal of Law, Policy and Globalization, vol.43, 2015, pp. 30-33.

[28] A. Abozaid, A.W. Dusuki, The challenges of realizing maqasid al-shariah in islamic banking and finance, Kuala Lumpur, 2007 [IIUM International Conference on Islamic Banking and Finance].

[29] M. H. Rashwan, H. Ehab, comparative efficiency study between islamic and traditional banks, Journal of Finance and Economics, vol. 4(3), 2016, pp. 74-87.

[30] A. W. Dusuki, Understanding the objectives of islamic banking: A survey of stakeholders' perspectives, International Journal of Islamic and Middle Eastern Finance and Management, vol. 1(2), 2008, pp. 132-148.

[31] A. W. Dusuki, S. Bouheraoua, The framework of Maqasid Al-Shari'ah and its implication for Islamic finance, Islam and Civilisational Renewal, vol. 2(2), 2011, pp. 316-336. 